\title{
Avaliando Pesquisa e Pesquisadores: um Título Inspirado e uma Realidade Complicada
}

\author{
Evaluation Research and Researchers: an \\ Inspired Title and a Complicated Reality
}

Aguinaldo Gonçalves ${ }^{I}$

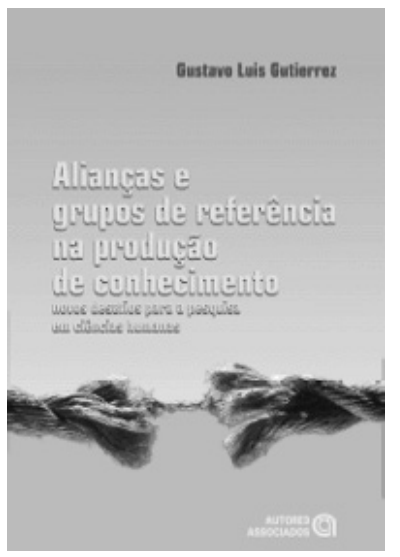

Resenha da obra de: Gutierrez GL. Alianças e grupos de referência na produção de conhecimento: novos desafios para a pesquisa em Ciências Humanas. Campinas: Editores Associados; 2005.

Comemorando a recente decisão deste periódico de criar e desenvolver uma seção de Resenhas, revela-se oportuno apropriar, para acesso e análise, livro recentemente disponível na realidade editorial brasileira que lida com dois componentes complementares, cada vez mais presentes e fundamentais da educação médica, porém aprofundados e até mesmo ventilados com freqüência inauditamente insuficiente. Trata-se de peculiaridades tanto da metodologia científica aplicada, quanto da respectiva crescente incorporação das chamadas ciências humanas em nossa área. De fato, a nós, multiplicadores de posturas, visões e valores no interior da escola médica, nos faz muito bem reunir elementos adequados para pensar melhor a comunidade científica pelas especificidades que aqui se põem: as perspectivas crítica e de poder.

Colega de área de atuação, o autor, professor Gustavo Gutierrez, situa-se também na militância docente, professor titular que é de mesma unidade da Unicamp. Trata-se aqui, portanto, de pessoa absolutamente habilitada a ter sua mais recente produção intelectual considerada, pois, como diz a professa Íris Ferrari, só se contraria a quem se gosta. Com efeito, a leitura deste seu livro motiva apreciação detalhada, a reiterar controvérsias e reinações entre companheiros de caminhada.

Obra formulada em cinco capítulos, o primeiro consiste, a partir de quadro sobretudo observacional e auto-referenciado, na acertada e agradável descrição de questões referentes à opção/formação do pós-graduando pelo referencial analítico que virá a adotar, fato reiterado repetidamente. Trata-se de identificadores de aplicação da psicologia corporativa da pesquisa, 
além de relatos de crônica de quem se sente bem na militância de seu exercício profissional. Tudo isto numa linguagem justa de polemista arguto.

Como ponto de partida, olhando a complexidade da produção na cena acadêmica, contrariamente a qualquer ingenuidade não mais cabível, observam-se pessoas estabelecendo alianças e identificando grupos de referências no intuito de se integrarem às elites universitárias. Estes são os determinantes, nas palavras do próprio professor Gutierrez, dos capítulos subseqüentes, nos quais envereda ele por ensaio sobre a formação histórica das elites e sua conexão com a geração do conhecimento. No interior dos mesmos, a abordagem formaliza-se, marcada por certo contraste com o coloquialismo do diálogo irônico anterior, que vinha sendo travado com evidente sustentação em autores clássicos e menções de mestres da literatura

Até aqui a leitura põe-se difícil para construir o entendimento a partir do título apresentado para a matéria contemplada. Mais ainda: entre seus segmentos constitutivos. Efetivamente não se desvela de imediato a procurada síntese entre a elaboração teórica lançada e a realidade empírica percebida. É de se cogitar que a isso conduzam, de algum modo, repetições viciosas de palavras, como à página 120, com “complexidade de uma escola de pensamento, ou que rompa com as escolas de pensamento estabelecidas e inaugura uma nova escola". Talvez haja no excerto algo de intencional, dada a existência de proposituras como "não se trata de aprofundar" (pág. 118); "não é o caso agora de desenvolver" (pág. 113); "a intenção é encaminhar reflexão mais imediata" (pág. 113); "não se trata de avançar na discussão" (pág. 119). Quiçá fosse possível recurso de superação o aclaramento do sentido conferido para certos vocábulos empregados, se o do senso comum ou o do significado preciso, como em nota de rodapé à página $80 \mathrm{com}$ a expressão "tecnologia apropriada" (em que se remete a referência bibliográfica especializada, para lidar com termo de tão amplo domínio em Ciência, Tecnologia e Desenvolvimento) ou à página 115 , com o conceito estatístico de aleatoriedade como eqüiprobabilidade de todos os elementos disponíveis para escolha, ou à página 117, com o epistêmico de caótico, como o reprodutivo previsível e regular dos fractais.

Na continuidade do trato da matéria, de tudo isso, no entanto, se acautela o capítulo 5. E mais houvesse para purgar, do mais seria redimido! Ocorre que surgem dois marcos efetivos na direção do entendimento de aspectos singulares da chamada comunidade científica, objetivo explícito do texto: são os construtos do paradoxo do desonesto e o do triunfo do maçom mutante. O primeiro, lembrando velhos percalços na lógica dos silogismos e dos sofistas, bem como nos meandros da teoria econômica, aponta que também em ciência "é impossível provar que a maioria das pessoas são desonestas porque ou eu sou honesto e a tese não se sustenta, ou eu sou desonesto e a tese é mentirosa" (pág. 140). Já o outro consiste na metáfora que busca entender alguém que, premido pelo sumiço das antigas amarras da divisão do mundo em esquerda e direita, e constrangido pela fragilidade da ética atualmente aplicada, mantém os segredos de sua corporação "tentando levar uns trocados para casa e, se possível, divertir-se um pouco, já que ninguém é de ferro" (pág. 163).

Em síntese, o livro leva a "perceber ciência e pesquisadores no contexto de uma sociedade caracterizada pela formação de elites e atravessada por conflitos que determinam os limites possíveis de sua evolução e o alcance de sua implementação na realidade concreta". Verdade ou cortina de fumaça? Defensivamente, as "considerações finais" (pág. 170) se preservam a respeito: lembram que o instrumental da pesquisa nas ciências humanas é sabidamente precário, não que seja muito melhor nas outras áreas, dada a já lançada provocação de tom projetivamente entre sisudo e farsesco (pág. 40), segundo a qual "dizem os médicos, entre outros, que em humanas, livre pensar é só pensar".

\section{ENDEREÇO PARA CORRESPONDÊNCIA}

Rua Luverci Pereira de Souza,1151

Cidade Universitária - Barão Geraldo

13 083-730 - Campinas - SP

E-mail: aguinaldo@fef.unicamp.br 